\title{
$\alpha$-Melanocyte Stimulating Hormone Prevents GABAergic Neuronal Loss and Improves Cognitive Function in Alzheimer's Disease
}

\author{
Keran Ma and JoAnne McLaurin \\ Department of Laboratory Medicine and Pathobiology, University of Toronto, Toronto, Ontario M5S 1A8, Canada
}

In Alzheimer's disease (AD), appropriate excitatory-inhibitory balance required for memory formation is impaired. Our objective was to elucidate deficits in the inhibitory GABAergic system in the TgCRND8 mouse model of AD to establish a link between GABAergic dysfunction and cognitive function. We sought to determine whether the neuroprotective peptide $\alpha$-melanocyte stimulating hormone $(\alpha$-MSH) attenuates GABAergic loss and thus improves cognition. TgCRND8 mice with established $\beta$-amyloid peptide pathology and nontransgenic littermates were treated with either $\alpha$-MSH or vehicle via daily intraperitoneal injections for $28 \mathrm{~d}$. TgCRND8 mice exhibited spatial memory deficits and altered anxiety that were rescued after $\alpha$-MSH treatment. The expression of GABAergic marker glutamic acid decarboxylase 67 (GAD67) and the number of GABAergic GAD67+ interneurons expressing neuropeptide Y and somatostatin are reduced in the hippocampus in vehicle-treated TgCRND8 mice. In the septohippocampal pathway, GABAergic deficits are observed before cholinergic deficits, suggesting that GABAergic loss may underlie behavior deficits in vehicle-treated TgCRND8 mice. $\alpha$-MSH preserves GAD67 expression and prevents loss of the somatostatin-expressing subtype of GABAergic GAD67+ inhibitory interneurons. Without decreasing $\beta$-amyloid peptide load in the brain, $\alpha$-MSH improves spatial memory in TgCRND8 mice and prevents alterations in anxiety. $\alpha$-MSH modulated the excitatory-inhibitory balance in the brain by restoring GABAergic inhibition and, as a result, improved cognition in TgCRND8 mice.

Key words: $\alpha$-melanocyte stimulating hormone; Alzheimer's disease; cognitive function; GABAergic system; somatostatin

\section{Introduction}

In Alzheimer's disease (AD), dysfunction of the cholinergic system exhibiting reduced choline acetyltransferase (ChAT) and acetylcholinesterase enzymatic activity and loss of ChAT + cholinergic cells have been reported (Perry et al., 1978; McGeer et al., 1984). However, in mild cognitive impairment and early AD, these cholinergic parameters are the same as those of agematched controls (Davis et al., 1999; Gilmor et al., 1999; DeKosky et al., 2002), suggesting that multiple neurotransmitter pathways may contribute to cognitive dysfunction.

To study cognitive deficits in $\mathrm{AD}$, many mouse models have been generated with a growing realization that dysfunction of the GABAergic system plays a role in $\mathrm{AD}$ pathogenesis. Loss of GABAergic interneurons has been reported, including a subtype of interneurons expressing the neuropeptide somatostatin (SST; Ramos et al., 2006; Perez-Cruz et al., 2011; Krantic et al., 2012).

Received Dec. 4, 2013; revised March 12, 2014; accepted April 7, 2014.

Author contributions: K.M. and J.M. designed research; K.M. performed research; K.M. and J.M. analyzed data; K.M. and J.M. wrote the paper.

This work was supported by Canadian Institutes of Health research grants (FRN37857;102467; J.M.), the Alzheimer's Society of Canada (J.M.), a Peterborough KM Hunter Graduate Studentship (K.M.), and an Alzheimer Society of Canada Biomedical Doctoral Award (K.M.). The authors thank Mary Brown for technical assistance.

The authors declare no competing financial interests.

Correspondence should be addressed to JoAnne McLaurin, PhD, Department of Laboratory Medicine and Pathobiology, 1 King's College Circle, Rm 6265, Toronto M5S 1A8, 0N, Canada. E-mail: j.mclaurin@utoronto.ca.

DOI:10.1523/JNEUROSCI.5075-13.2014

Copyright $\odot 2014$ the authors $\quad 0270-6474 / 14 / 336736-10 \$ 15.00 / 0$
SST expression is consistently reduced in the CSF, hippocampus, and cortex of $\mathrm{AD}$ patients, and it is correlated with cognitive dysfunction (Davies and Terry 1981; Tamminga et al., 1987; Dournaud et al., 1994; Tuboly and Vécsei, 2013). Hippocampal SST-expressing GABAergic interneurons provide inhibitory innervation to local principal cells and long-range projections to the septum and enthorinal cortex. These interneurons modulate the highly synchronized theta activity underlying spatial/temporal coding important for spatial memory (Katona et al., 1999; Melzer et al., 2012). Dysfunction of the somatostatinergic system may contribute to memory, cognitive, and emotional changes in $\mathrm{AD}$.

TgCRND8 mice express the human amyloid precursor protein (APP) containing Swedish and Indiana mutations, resulting in cognitive deficits starting at 2 months of age and progressing with $\beta$-amyloid peptide (A $\beta$ ) accumulation (Chishti et al., 2001; Francis et al., 2012a). In addition, susceptibility to seizures, LTPchanges, and loss of glutamic acid decarboxylase (GAD)immunoreactive GABAergic neurons have been reported (Jolas et al., 2002; Del Vecchio et al., 2004; Krantic et al., 2012). An imbalance of excitation and inhibition in this model suggested to us that GABAergic intervention is critical for stabilization of cognitive function. We propose that preservation of GABAergic cells will restore the physiological environment for normal function and provide an advantage over GABAergic drug interventions presently available (Lanctôt et al., 2004). 
$\alpha$-Melanocyte stimulating hormone ( $\alpha$-MSH), a cleavage product of pro-opiomelanocortin, is reduced in the brain and CSF of AD patients and $\alpha$-MSH autoantibody levels correlate with cognitive dysfunction (Arai et al., 1986; Rainero et al., 1988; Costa et al., 2011). $\alpha$-MSH exhibits many neuroprotective effects that may rescue neuronal degeneration: upregulation of cAMP response element-binding protein phosphorylation (Sarkar et al., 2002), induction of brain-derived neurotrophic factor (Caruso et al., 2012), neurogenesis (Giuliani et al., 2011), increased viability of hippocampal pyramidal cells (Forslin Aronsson et al., 2006, 2007), and upregulation of activity-dependent genes (Giuliani et al., 2009). A potent synthetic analog of $\alpha$-MSH also improved spatial memory in a 3xTg (APPSwe/PS1M146V/TauP301L) mouse model of AD (Giuliani et al., 2014). In light of these results and the expression of hippocampal $\alpha$-MSH receptors, we propose that $\alpha$-MSH treatment represents a proof-of-concept strategy for preservation of GABAergic interneurons to improve cognitive function.

\section{Materials and Methods}

Animals. Male and female TgCRND8 mice, harboring the human Swedish (KM670/671NL) and Indiana (V717F) APP mutations, and their nontransgenic littermates (NTg) were used in this study. Mice were maintained on an outbred C3H/C57BL6 background and kept on a $12 \mathrm{~h}$ light/dark cycle with food and water ad libitum. All experiments were performed in accordance with Canadian Council for Animal Care and University of Toronto guidelines.

Drug Treatment. TgCRND8 mice and NTgs were evenly divided per litter and by gender into $\alpha$-MSH-treated or saline vehicle-treated groups. $\alpha-\mathrm{MSH}$, supplied as a trifluoroacetate salt (Bachem) was dissolved in sterile saline and administered via daily intraperitoneal injections of 0.5 mg/kg (Huang and Tatro, 2002; Forslin Aronsson et al., 2006, 2007). Drug treatment was initiated when mice were 20 weeks of age for $28 \mathrm{~d}$. Animals were killed at 24 weeks of age by anesthetizing with pentobarbital $(60 \mathrm{mg} / \mathrm{kg})$ followed by transcardial perfusion with PBS, pH 7.4. Brain tissues for biochemical analysis were dissected at $4^{\circ} \mathrm{C}$ and flash frozen on dry ice. Brain tissues for immunohistochemistry and immunofluorescence analyses were transcardially fixed with Zamboni fixative, sectioned using a freezing microtome at $40 \mu \mathrm{m}$, and stored at $-20^{\circ} \mathrm{C}$ in cryoprotectant.

Behavioral tests. Animals were handled for $3 \mathrm{~d}$ before behavioral testing and acclimatized to the testing room before each testing session. The open field test and the Y-maze test were performed 2-3 d before drug treatment and at the end of drug treatment. In the open field test, each mouse was placed in an arena $(25 \mathrm{~cm}$ wide $\times 47 \mathrm{~cm}$ wide $\times 19 \mathrm{~cm}$ high $)$ to freely explore for $10 \mathrm{~min}$ (Prut and Belzung, 2003). In the forced trial Y-maze, one arm was closed off and each mouse explored the maze for 10 $\mathrm{min}$. After $90 \mathrm{~min}$, alternation behavior in all three arms was recorded for $5 \mathrm{~min}$. The Y-maze test is a test for spatial memory and spontaneous alternation behavior in the Y-maze is very sensitive to hippocampal dysfunction (Lalonde, 2002; Deacon and Rawlins, 2006; Sharma et al., 2010). The Y-maze is less stressful on the mice than other memory tasks, thus decreasing potential confounds due to elevated corticosterone levels (Harrison et al., 2009; Kennard and Woodruff-Pak, 2011). Exploratory behavior for both tasks was recorded using Logitech webcam Pro9000 and analyzed with Viewpoint VideoTrack 3.0. Spontaneous alternation in the Y-maze was calculated using the following formula: percentage alternation $=$ [number of alternations/(total number of arms entries 2)] $\times 100$.

$A \beta$ ELISA. Concentrations of formic acid-extracted total $A \beta 42$ and $A \beta 40$ and diethylamine-extracted soluble $A \beta 42$ and $A \beta 40$ were determined using commercially available sandwich ELISA kits (Invitrogen), as previously described (McLaurin et al., 2006). Standards and unknown samples were run in triplicate.

Immunohistochemistry. Brain sections $40 \mu \mathrm{m}$ thick from 5-11 animals per treatment group were used for immunohistochemistry. For each antibody, 4-6 sections per animal from the same bregma coordinates were stained and quantification was done on both hippocampi per sec- tion. All sections were treated with $0.3-0.6 \% \mathrm{H}_{2} \mathrm{O}_{2}$ and blocked with $7.5 \%$ donkey serum in PBS plus 0.3\% Triton X-100 (Cui et al., 2011). A $\beta$ plaque staining using $6 \mathrm{~F} / 3 \mathrm{D}$ antibody required an additional antigen retrieval step using 70\% formic acid for 5 min (Chishti et al., 2001; McLaurin et al., 2006). Primary and secondary antibodies were diluted in $7.5 \%$ donkey serum in PBS plus $0.3 \%$ Triton X-100. The following antibodies were used in our study: mouse anti-human 6F/3D IgG1 $\kappa(1: 400$; Dako), mouse anti-GAD67 IgG2a (1:1000; Millipore), rat anti-SST IgG2b (1:400; Millipore), goat anti-ChAT IgGs (1:400; Millipore), biotinylated horse anti-mouse IgG [heavy and light chains $(\mathrm{H}+\mathrm{L}), 1: 400$; Vector], biotinylated rabbit mouse adsorbed anti-rat IgG (H+L, 1:100; Vector), and biotinylated donkey anti-goat IgG (H+L, 1:200; Vector). Vector $\mathrm{ABC}$ kit was used to amplify the antigen signal and staining was visualized with 3,3'-diaminobenzidine and nickel chloride (Vector). Images of all sections were taken using a Leica DMI3000 inverted microscope and quantified using ImageJ. Quantification of $A \beta$ plaques and ChAT staining was done using appropriate threshold and particle size settings on ImageJ. GAD67+ and SST + cell quantification was done manually by a blind observer using the Image cell counter plugin.

Immunofluorescence. Brain sections $40 \mu \mathrm{m}$ thick were blocked with 7.5\% donkey serum in PBS plus $0.3 \%$ Triton X-100 and incubated in primary and secondary antibodies diluted in $7.5 \%$ donkey serum in PBS plus $0.3 \%$ Triton X-100 (Cui et al., 2011). Dilutions for Millipore primary antibodies mouse anti-GAD67 IgG2a and rat anti-SST IgG2b were 1:400 and 1:200 respectively. Alexa Fluor-conjugated secondary antibodies goat antimouse IgG $(\mathrm{H}+\mathrm{L})$ conjugated to Alexa Fluor 488 and goat anti-rat IgG $(\mathrm{H}+\mathrm{L})$ conjugated to Alexa Fluor 594 were used for antigen visualization. Images were taken with Leica TSC SP5 confocal microscope.

Immunoblotting. Brain hippocampal tissue was homogenized in RIPA buffer (150 mm NaCl, 1\% Triton X-100, 0.5\% sodium deoxycholate, $0.1 \%$ SDS, 50 mu Tris, $\mathrm{pH} 8.0$, and protease inhibitors). Sample protein concentrations were determined using the BCA kit from Pierce. All samples were denatured and reduced, separated on a $4-12 \%$ Bis-tris gel and transferred using iBlot onto nitrocellulose membranes. Membranes were blocked with $5 \%$ milk in TBST $(0.02 \%$ Tween). Primary and secondary antibodies were diluted in 5\% milk in TBST and membranes were developed with enhanced chemiluminescence (GE Healthcare). Primary antibodies used were mouse anti-GAD67 IgG2a (1:7500; Millipore) and rabbit anti-GAD65 IgGs (1:1000; Millipore). Secondary antibodies used were goat anti-mouse $\operatorname{IgG}(\mathrm{H}+\mathrm{L}, 1: 5000$; Thermo Scientific $)$ and goat anti-rabbit IgGs (1:2000; Santa Cruz Biotechnology). Optical intensity of target proteins and their respective protein loading control, GAPDH, were measured using ImageJ.

Quantitative real-time PCR. Hippocampal RNA was isolated using Aurum Total RNA Fatty and Fibrous Tissue Pack from Bio-Rad as per manufacturer's instructions ( $n=6-7$ per treatment group). Isolated RNA was DNase treated. The purity and integrity of the RNA were verified spectrophotometrically using absorbance wavelength 260/280 and 260/230 ratios and by electrophoresis on agarose gels. cDNA from the RNA was made using the Bio-Rad kit iScript Reverse Transcription Supermix for quantitative real-time PCR. All primer pairs except $\beta$-actin were designed using Beacon Designer (Francis et al., 2012b) and only primer pairs with efficiencies of $90-110 \%$ with no secondary byproducts were used. All samples used in real-time PCR were run in triplicates on the Bio-Rad CFX384 Touch real-time PCR detection system using the SsoAdvanced SYBR Green Supermix (Biorad). Data were analyzed with CFX Manager as ratios of target gene/ $\beta$-actin. Of the housekeeping genes tested, $\beta$-actin, TATA, GAPDH, S18 and YWAHZ, $\beta$-actin expression was even across genotype and $\alpha$-MSH treatment using $n=7$ per group. Therefore, $\beta$-actin was chosen as the housekeeping gene. Table 1 lists the primer pairs used in this study.

Statistical analysis. The change between pretreatment and posttreatment in the Y-maze and open field tests were analyzed using twoway ANOVAs with treatment and genotype as "between-subject" factors. $\mathrm{A} \beta$ concentration and $\mathrm{A} \beta$ plaque data were analyzed using Student's $t$ test. All other data were analyzed using one-way ANOVAs with Fisher's LSD post hoc test. Statistical analyses were performed using IBM SPSS Statistics 20 with significance set at $p<0.05$. 
Table 1. Quantitative real-time $P C R$ primer pairs

\begin{tabular}{|c|c|c|}
\hline Primers & Forward $5^{\prime}$ to $3^{\prime}$ & Reverse 5' to 3' \\
\hline GAD67 & CAGCCAGACAAGCAGTAT & TTCCACATCAGCCAGAAC \\
\hline SST & TGAGCAGGACGAGATGAG & CAGGAGTTAAGGAAGAGATATGG \\
\hline NPY & GTGTGTTTGGGCATTCTG & GGTGATGAGATTGATGTAGTG \\
\hline CCK & CCGAGGACTACGAATACC & CAGACATTAGAGGCGAGG \\
\hline VIP & CAGAAGCAAGCCTCAGTT & TCCAGCCTACTCACTACAG \\
\hline$\beta$-Actin & AGCCATGTACGTAGCCATCC & СTCTCAGCTGTGGTGGTGAA \\
\hline YWAHZ & ACAGCAAGCATACCAAGAA & ATAGAACACAGAGAAGTTGAGG \\
\hline S18 & TACTCAACACCAACATCG & СТTTССТСААСАССАСАT \\
\hline TATA & GCCTTCCACCTTATGCTCAG & GAGTAAGTCCTGTGCCGTAAG \\
\hline GAPDH & AAGAAGGTGGTGAAGCAGGCATC & CGAAGGTGGAAGAGTGGGAGTTG \\
\hline
\end{tabular}

\section{Results}

\section{$\alpha$-MSH preserves spatial memory in TgCRND8 mice}

To determine whether $\alpha$-MSH treatment preserves cognitive function, TgCRND8 mice and NTgs were randomly divided into four sex-balanced groups and each genotype was administered intraperitoneally $\alpha$-MSH or vehicle ( $n=10-23$ mice per group). Treatment was initiated therapeutically at 20 weeks of age for $28 \mathrm{~d}$, when $\mathrm{A} \beta$ pathology and behavioral deficits were well established in TgCRND8 mice (Chishti et al., 2001; McLaurin et al., 2006). We have previously used the Morris Water Maze (MWM) test of spatial learning in the TgCRND8 mice (Janus et al., 2000; McLaurin et al., 2006). We presently used the Y-maze test because the MWM test is more motor taxing and stressful than the land-based Y-maze test. In particular, Harrison et al., 2009 showed that mice matched for performance on standard anxiety tests exhibited greater plasma corticosterone levels in response to the MWM test than in response to land-based testing. Most importantly, visual-spatial learning was inversely related to corticosterone levels in the MWM test. The Y-maze test demonstrates comparable sensitivity to the reference memory version of the MWM test for detection of spatial memory deficits (Stewart et al., 2011). In vehicle-treated TgCRND8 mice, we observe a decline in the Y-maze spontaneous alternation test between 20 and 24 weeks of age (Fig. 1A). The spontaneous alternation analysis of the Y-maze task uses a mouse's natural tendency to visit novel spaces. Therefore a high percentage alternation score relies on the mouse's ability to recall which arm was last visited. TgCRND8 mice and NTgs were tested in the Y-maze test both before and after treatment to assess mouse-specific responses.

At 24 weeks of age, TgCRND8 mice exhibit a decrease in spontaneous alternation that was prevented after $\alpha$-MSH treatment (Fig. 1A-C). Two-way ANOVA analysis of the change in percentage alternation between pretreatment and post-treatment showed a significant interaction between $\alpha$-MSH treatment and genotype $\left(F_{(1,61)}=4.62, p=0.036\right.$; Fig. $\left.1 A\right)$. $\alpha$-MSH treatment significantly improved percentage alternation in TgCRND8 mice $(p<0.001)$ with no effect on NTg mice. At 20 weeks of age, before treatment, TgCRND8 mice did not show a significant decrease in percentage alternation, suggesting intact spatial memory in the Y-maze task (Fig. $1 B$ ). However by 24 weeks of age, TgCRND8 vehicle-treated mice showed a significant decrease in percentage alternation, indicating deficits in spatial memory (Fig. $1 C)$. Four weeks of $\alpha$-MSH treatment preserved spatial memory in TgCRND8 mice (Fig. $1 A, C$ ).

$\alpha$-MSH maintains normal anxiety levels in TgCRND8 mice Decreased anxiety has been previously shown in the TgCRND8 mice compared with NTgs after housing in an enriched environment using the elevated plus-maze test (Görtz et al., 2008). Like- wise, $\operatorname{Tg} 2576$ mice exhibit less anxiety with increasing $\mathrm{A} \beta$ load (Ognibene et al., 2005). To determine potential effects of $\alpha$-MSH on anxiety, we used the open field test and compared exploration of the center versus the periphery of the field as a measure of anxiety (Prut and Belzung, 2003). Two-way ANOVA analysis of center field activity between pretreatment and post-treatment demonstrated a significant drug-genotype interaction in the amount of the time spent in the center $(n=10-23$ per group; $F_{(1,68)}=6.24, p=0.015$; Fig. $\left.1 D\right)$ and the distance traveled in the center $\left(F_{(1,68)}=5.89, p=0.018\right)$. As previously shown, vehicletreated TgCRND8 mice became less anxious with age compared with NTgs with significant main genotype effects of time spent in center and distance traveled within the center $(p=0.035$ and $p=$ 0.029 respectively; Fig. $1 E, F) . \alpha-\mathrm{MSH}$ treatment normalized anxiety in TgCRND8 mice as indicated by the amount of time spent $(p=0.008)$ and distance traveled in the center field ( $p=$ 0.002 ) as outcome measures. Our results demonstrate that $\alpha$-MSH treatment normalized anxiety levels in the TgCRND8 mice to those of NTg mice (Fig. 1D-F).

\section{$\alpha$-MSH does not affect locomotion}

To investigate whether the change in anxiety is confounded by changes in locomotion, we further examined parameters of the open field test. TgCRND8 mice showed a significant increase in locomotion compared with NTgs as assessed by the total distance traveled, duration of inactivity (movement of $<1 \mathrm{~cm} / \mathrm{s}$ ), and number of rotations (circling behavior). Two-way ANOVA analysis of changes in all three measurements between pretreatment and post-treatment showed significant genotype effect where TgCRND8 mice are more hyperactive compared with NTgs $(p<$ $0.001)$. There were no significant drug-genotype interaction in total distance $\left(F_{(1,68)}=0.02, p=0.887\right.$; Fig. $\left.1 G\right)$, inactive duration $\left(F_{(1,68)}=0.91, p=0.344\right)$, and rotation $\left(F_{(1,68)}=1.52, p=\right.$ 0.222 ). Regardless of age and $\alpha-\mathrm{MSH}$ treatment, TgCRND8 mice are more hyperactive than NTgs. These data suggest that locomotion did not affect measures of anxiety (Fig. $1 G-I$ ).

\section{$\alpha$-MSH-mediated cognitive improvement is independent of A $\boldsymbol{\beta}$ plaque load}

To determine whether a reduction in $\mathrm{A} \beta$ load underlies the behavioral benefits of $\alpha$-MSH treatment, $\mathrm{A} \beta 40$ and $\mathrm{A} \beta 42$ peptide concentrations were examined in the hippocampus and cortex of TgCRND8 brains ( $n=5$ mice per group). Since our behavioral readout measures require intact cortical-hippocampal function, we investigated potential changes to $A \beta$ peptide load in both regions. No significant differences in soluble or insoluble $\mathrm{A} \beta 40 / \mathrm{A} \beta 42$ were observed between vehicle-treated and $\alpha$-MSHtreated TgCRND8 mice (Fig. 2A-D). Previous studies in TgCRND8 mice have shown treatment-induced decreases in A $\beta$ plaque burden without a concomitant decrease in $\mathrm{A} \beta$ levels (Janus et al., 2000; Hawkes et al., 2012). In light of the even distribution of $\alpha$-MSH throughout the brain (Wilson, 1988), we chose to quantify $\mathrm{A} \beta$-plaque load in the hippocampus only $(n=$ 6 mice per group). Quantification of A $\beta$ plaques showed no statistical difference between vehicle-treated and $\alpha$-MSH-treated TgCRND8 mice either by the number of plaques $(t=0.37, \mathrm{df}=$ $10, p=0.72$; Fig. $2 E, G, H)$ or percentage area covered by plaques in the hippocampus $(t=0.45, \mathrm{df}=10, p=0.66$; Fig. $2 F-H)$. Since $A \beta$ load in the TgCRND8 brain was unchanged, preservation of behavior elicited by $\alpha$-MSH treatment may be independent of $A \beta$. 
A
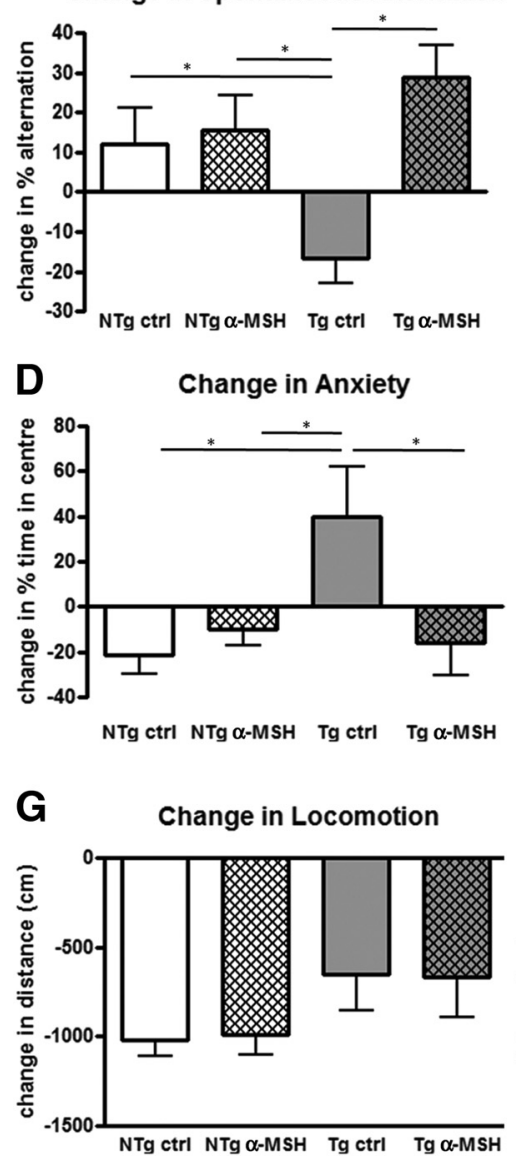

B
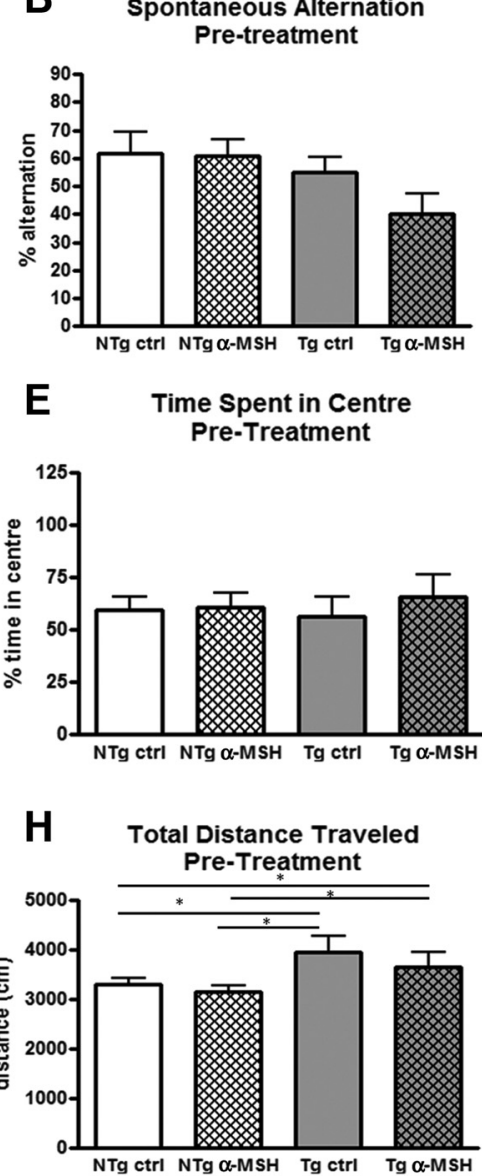
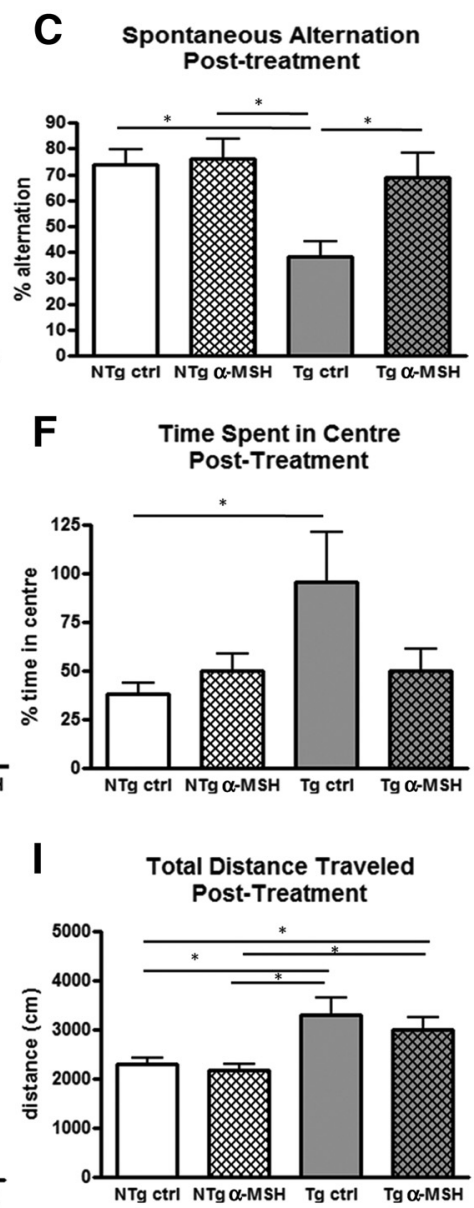

Figure 1. Effects of $\alpha$-MSH on behavior in TgCRND8 mice. Spontaneous alternation analysis of the $Y$-maze was used to assess the spatial memory of mice. $A$, The change in percentage alternation shows a significant $\alpha$-MSH treatment- genotype interaction $(p=0.036)$. B, At 20 weeks of age, TgCRND8 mice did not exhibit deficits in spatial memory. C, However, at 24 weeks of age, TgCRND8 mice showed a significant decrease in percentage alternation. $A, C, \alpha$-MSH treatment improved spatial memory in $\operatorname{TgCRND8}$ mice $(p<0.001)$ with no effect on non-Tg littermates $(p=0.786)$. $\boldsymbol{D}$, In the open field test, there is a significant interaction between $\alpha$-MSH treatment and genotype $(p=0.015) . \boldsymbol{E}, \boldsymbol{F}, \operatorname{TgCRND8}$ vehicle-treated mice showed a significant decrease in anxiety from 20 to 24 weeks of age and $\alpha$-MSH treatment prevented this change $(p=0.008)$. Locomotion of mice was also measured in the open field test. $G$, There is no significant interaction between $\alpha$-MSH treatment and genotype in the total distance traveled $(p=0.887) . \mathbf{H}, \mathbf{I}$, Both vehicle-treated and $\alpha$-MSH-treated TgCRND8 mice are more hyperactive compared with non-Tg mice $(p<0.001)$. NTg ctrl, Vehicle-treated NTg mice; NTg $\alpha$-MSH, $\alpha$-MSH-treated NTg mice; Tg ctrl, vehicle-treated Tg mice; Tg $\alpha$-MSH, $\alpha$-MSH-treated Tg mice. Data represent mean \pm SEM, $n=10-23$ per group, ${ }^{*} p<0.05$.

$\alpha$-MSH rescues GABAergic deficits in TgCRND8 mice

Disruption of the GABAergic system interferes with the synchrony of neuronal networks in the hippocampus and leads to cognitive impairment and seizures (Katona et al., 1999; Palop et al., 2007; Melzer et al., 2012). GAD converts glutamic acid to GABA and is commonly used as a marker of GABAergic interneurons. The two isoforms, GAD67 and GAD65, are predominantly localized in GABAergic cell bodies and axon terminals, respectively (Esclapez et al., 1994). TgCRND8 mice exhibit GABAergic deficits that are attenuated by $\alpha$-MSH treatment. One-way ANOVA analyses of GABAergic markers revealed that GAD67 mRNA levels were significantly decreased in 24-week-old TgCRND8 vehicle-treated mice compared with NTgs (vehicle, $p=0.044 ; \alpha$-MSH, $p=0.007)$, whereas $\alpha$-MSH maintained GAD67 mRNA levels in TgCRND8 mice to that of NTg mice $(n=$ 6-7 mice per group; Fig. 3A). GAD67 protein levels in TgCRND8 vehicle-treated mice are decreased compared with NTgs (vehicle, $p=0.001 ; \alpha$-MSH, $p=0.016) . \alpha$-MSH-treated TgCRND8 mice expressed GAD67 protein levels comparable to NTg mice $(n=$ 6-7 mice per group; Fig. 3B). However, GAD65 protein levels were not changed with genotype or $\alpha$-MSH treatment ( $n=6-7$ mice per group; Fig. $3 C$ ). Furthermore, $\alpha$-MSH had no effect on
NTg mice compared with vehicle-treated NTg mice. In the CA1 region of the hippocampus, the number of GAD67+ cells are decreased in vehicle-treated TgCRND8 mice compared with NTg mice (vehicle, $p=0.018 ; \alpha-\mathrm{MSH}, p=0.001$ ); $\alpha$-MSH treatment prevented the loss of GAD67+ cells in TgCRND8 mice $(p=$ $0.016)$ and had no effect on GAD67+ cells in NTg mice $(n=6$ mice per group; Fig. $4 A, D-G$ ). In the $C A 3$ region and hilus of the hippocampus, the number of GAD67+ cells is not altered by genotype or $\alpha-\mathrm{MSH}$ treatment at 24 weeks of age ( $n=6-7$ mice per group; Fig. $4 B, C$ ). These results suggest that preservation of GABAergic neuronal function in the CA1 region of the hippocampus may contribute to improved behavior after $\alpha$-MSH treatment.

\section{GABAergic deficits precede cholinergic deficits}

Our results demonstrate spatial memory and anxiety deficits in 24-week-old TgCRND8 mice with a coexisting loss of GABAergic interneurons in the hippocampus. To determine whether GABAergic changes are the primary contributor to cognitive dysfunction at this age, and in light of the cholinergic neuronal loss in the nucleus basalis-cortical pathway previously reported in this model (Bellucci et al., 2006), we examined the cholinergic neu- 
rons in the septum of TgCRND8 mice. In the septohippocampal pathway, at 24 weeks of age, the number of ChAT + cells and the area per ChAT + cell in the septum were not statistically different between TgCRND8 mice and NTg mice (ANOVA: vehicle, $p=0.38 ; \alpha-\mathrm{MSH}, p=$ 0.88; Fig. $5 A-F)$. $\alpha$-MSH treatment had no effect on either the number or area of ChAT + cells in TgCRND8 (ANOVA: number, $p=0.57$; area, $p=0.95$ ) or NTg mice (ANOVA: number, $p=0.46$; area, $p=0.77 ; n=6$ mice per group; Fig. $5 A-$ $F)$. GABAergic GAD67+ cell loss in the hippocampus precedes cholinergic ChAT + cell loss in the septum of TgCRND8 mice.

$\alpha$-MSH preserves SST-immunoreactive neurons in the hippocampus

To further characterize a potential link between $\alpha$-MSH-mediated improvement in behavior and preservation of GABAergic neurons, subpopulations of GABAergic neurons according to the neuropeptide expression were examined ( $n=6-7$ mice per group). In the hippocampus, cells containing SST, neuropeptide Y (NPY), cholecystokinin (CCK), and vasoactive intestinal polypeptide (VIP) are almost exclusively GABAergic neurons (Freund and Buzsáki, 1996). Investigation of neuropeptide expression to examine GABAergic neuronal subtypes has not been previously reported in the TgCRND8 mouse at any age. One-way ANOVA analyses of our results revealed a significant decrease of both NPY $(p=0.01)$ and SST $(p=$ 0.038) mRNA levels in TgCRND8 mice compared with NTg mice (Fig. 6A,B). The mRNA levels of the neuropeptides CCK (Fig. 6C) and VIP (data not shown) were not affected by either genotype or treatment. $\alpha$-MSH treatment did not pre-

vent NPY mRNA loss in TgCRND8 mice (Fig. 6A). In contrast, SST mRNA levels in the hippocampus of $\alpha$-MSH-treated TgCRND8 mice were significantly greater than those of vehicletreated TgCRND8 mice ( $p=0.011)$, and not statistically different from those of vehicle-treated or $\alpha$-MSH-treated NTg mice (Fig. 6B). SST + cells in the CA1 region of the hippocampus are mostly localized in the stratum oriens. The number of SST + cells in the stratum oriens of the CA1 was significantly decreased in TgCRND8s compared with NTgs (vehicle, $p=0.038 ; \alpha-\mathrm{MSH}$, $p=0.018$; Fig. $7 A, D-F) . \alpha$-MSH treatment prevented the loss of SST + cells $(p=0.011 ; n=6$ mice per group; Fig. $7 A, D-G)$. In the CA3 region and hilus of the hippocampus, the number of $\mathrm{SST}+$ cells is not affected by genotype or $\alpha$-MSH treatment $(n=$ $6-11$ per group; Fig. $7 \mathrm{~B}, \mathrm{C}$ ). Confocal images in Figure $7 \mathrm{H}$ show the colocalization of GAD67 + cells and SST + cells in the stratum oriens of the CA1. Subpopulation analysis of GABAergic neurons demonstrated that GAD67+ cell loss in the CA1 region of the hippocampus is in part due to the loss of the SST + subpopulation. The loss of GAD67-expressing and SST-expressing cells in the hippocampus of TgCRND8 mice is restricted to the CA1 region. $\alpha$-MSH treatment maintained the number of GAD67+ cells and SST + cells in the CA1 region of TgCRND8 mice to levels comparable to those of NTg mice. In conclusion, preservation of the specific SST-expressing subtype of GABAergic neurons in the CA1 of the hippocampus may contribute to improved cognitive function in $\alpha$-MSH-treated TgCRND8 mice.

\section{Discussion}

TgCRND8 mice develop spatial memory deficits and decreased anxiety between 20 and 24 weeks of age with concomitant loss of hippocampal GAD67+ GABAergic interneurons in the CA1 region. The number of GAD67+ interneurons in the CA3 and hilus of the hippocampus is not statistically different between TgCRND8 and NTg mice. In 24 week-old TgCRND8 mice, the decrease of GAD67 + cells in the CA1 through CA3 region previously observed by Krantic and colleagues may be accounted for by the decrease in the CA1 region because our results demonstrate no changes in the CA3 region (Krantic et al., 2012). Our examination of GABAergic interneuron subtypes demonstrated that, in 

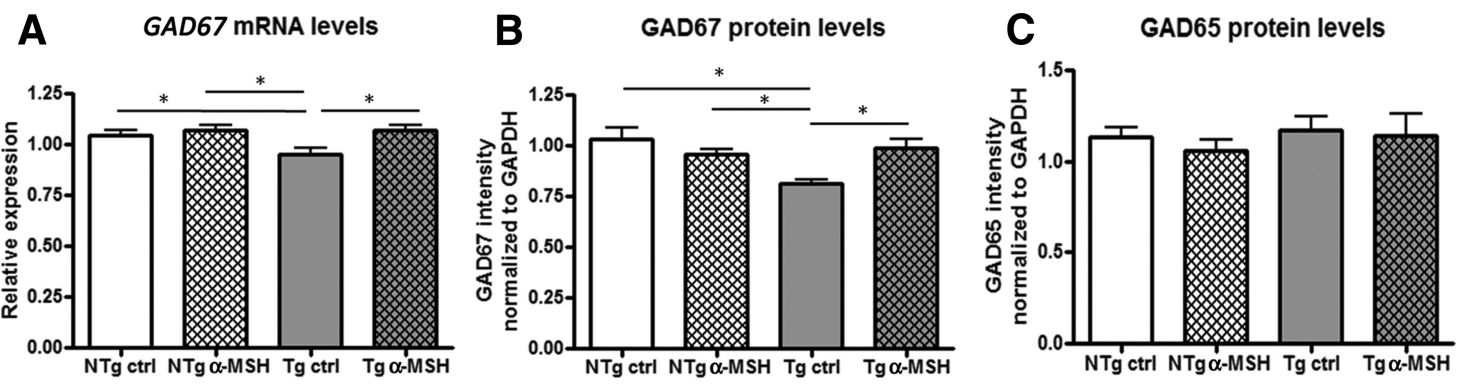

Figure 3. GABAergic marker expression in the hippocampus. $\boldsymbol{A}, \boldsymbol{B}, \mathrm{GAD} 67 \mathrm{mRNA}(\boldsymbol{A})$ and protein levels $(\boldsymbol{B})$ are significantly decreased in $\operatorname{TgCRND8}$ mice compared with non-Tg littermates $(p=$ 0.044 and $p=0.001$ respectively). C, GAD65 protein levels are not changed with genotype or $\alpha$-MSH treatment. $\alpha$-MSH treatment rescues the GAD67 deficits in TgCRND8 mice in both mRNA ( $p=$ $0.008)$ and protein levels $(p=0.009)$. Data represent mean \pm SEM, $n=6-7$ per group, ${ }^{*} p<0.05$.

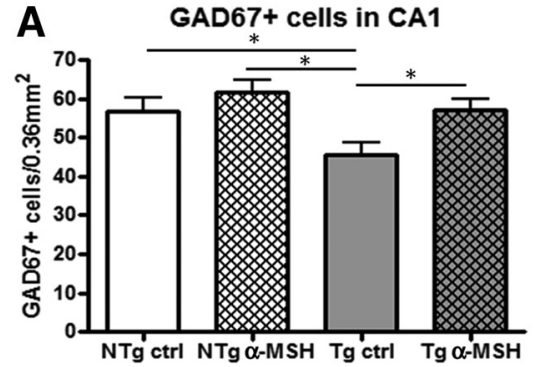

\section{B}

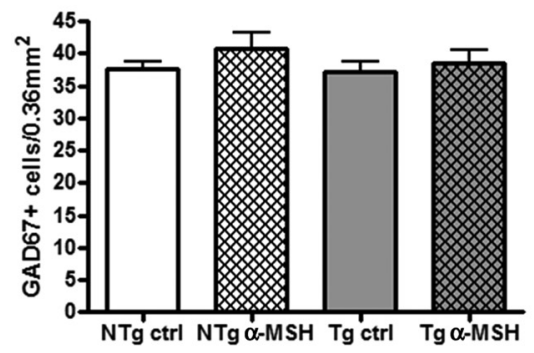

C

GAD67+ cells in hilus

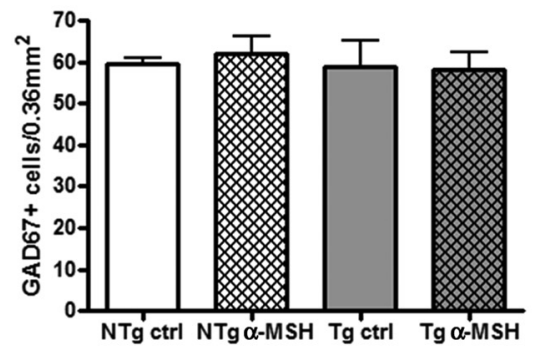

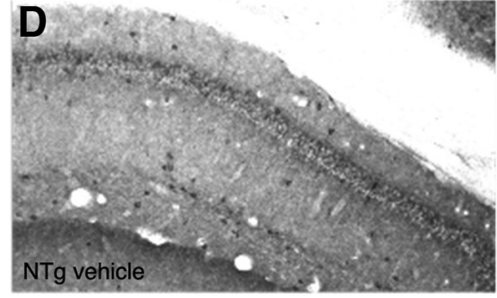
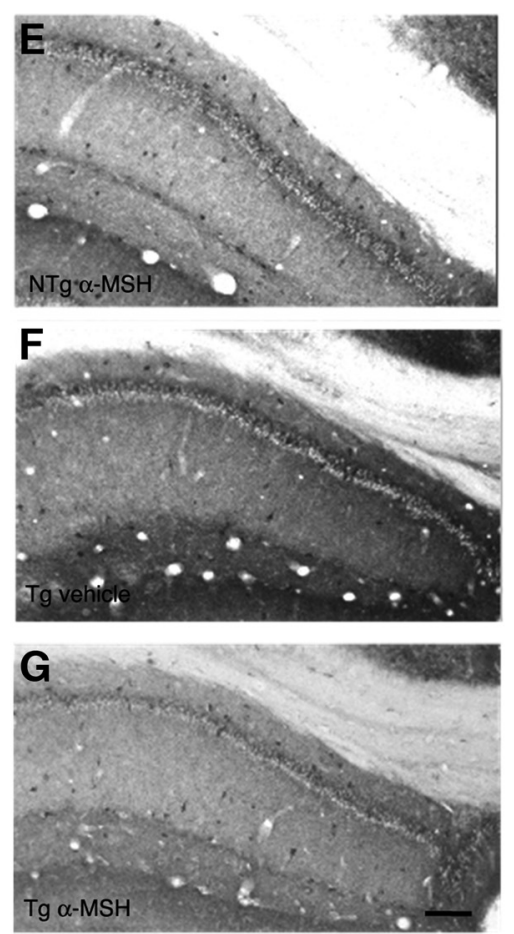

Figure4. Effect of $\alpha$-MSH treatmentonGABAergicGAD67+ interneuronsinthehippocampus.A, Thelownumber ofGAD67 + cells intheCA1 region of the hippocampus in $\operatorname{TgCRND8}$ mice $(p=0.018 ; \mathrm{A})$ increases with $\alpha$-MSH treatment $(p=0.016)$. B, C, Neither genotype nor $\alpha$-MSH treatment changed the number of GAD67 + cells in the $C A 3$ region $(B)$ or the hilus $(\boldsymbol{C}$ ) f the hippocampus. $D-G$, Representative photomicrographs of the GAD67 + GABAergic intemeurons in the CA1 region of the hippocampus in NTg vehicle-treated (D), NTg $\alpha$-MSH-treated (E), Tg vehicletreated $(\boldsymbol{F})$, and Tg $\alpha$-MSH-treated (G) mice. Data representmean \pm SEM, $n=6-7$ per group, ${ }^{*} p<0.05$. Scale bar, $100 \mu \mathrm{m}$.

TgCRND8 mice, the lost GAD67+ GABAergic interneurons are SSTexpressing and NPY-expressing subtypes. Our results show that the number of SST + cells in the CA1 stratum oriens of the hippocampus is significantly less in TgCRND8 mice compared with NTg mice. We did not detect GABAergic cell loss in the CA3 or the hilus of the hippocampus. However, we cannot rule out cell loss with more advanced disease in these mice. Our results are consistent with previous reports that showed decreased tonic inhibition leading to increased long-term potentiation in the CA1 region (Jolas et al.,
2002) and increased seizure threshold and severity in TgCRND8 mice (Del Vecchio et al., 2004). Our results are also consistent with the age-dependent deficits in multiple cognitive systems in the TgCRND8 mice (Hyde et al., 2005; Hanna et al., 2009).

GABAergic interneuron loss has been previously reported in mouse models of AD (Ramos et al., 2006; Perez-Cruz et al., 2011; Krantic et al., 2012; Loreth et al., 2012). Similar to our results, $\mathrm{Tg} 2576$ mice overexpressing human APPswe demonstrate a loss of hippocampal SST + cells in the CA1 region but not the dentate gyrus (Perez-Cruz et al., 2011). Krantic and colleagues also did not detect a loss of GAD67+ cells in the dentate gyrus of TgCRND8 mice (Krantic et al., 2012). In $A P P \times P S 1$ mice, a loss of SST and NPY GABAergic neurons was detected in all regions of the hippocampus (Ramos et al., 2006). This group demonstrated that PS1 mice did not have a loss and suggested that the GABAergic neuronal loss could be attributed to $A \beta$. In contrast, J20 mice that overexpress APP showed decreased GABAergic neurons of the parvalbumin (PV) and calretinin subtype in the septohippocampal pathway. The loss of PV neurons resulted in network dysfunction and increased spontaneous epileptiform activity (Rubio et al., 2012; Verret et al., 2012). In TauPS2APP mice, the hyperactive phenotype and spatial memory deficits were linked to loss of $\mathrm{NPY}+, \mathrm{PV}+$, and calretinin + GAD67+ cells in the dentate gyrus without a loss of SST + or cholinergic cells (Loreth et al., 2012). The difference in subtype loss between the $\mathrm{AD}$ mouse models may be linked to genetic background, expression of other transgenes, gender differences, and level of $\mathrm{A} \beta$ expression.

The two greatest risk factors for sporadic AD are ApoE4 expression and aging. Rodent models of both demonstrate that GABAergic neuronal loss is linked to cognitive deficits (AndrewsZwelling et al., 2010; Leung et al., 2012; Stanley et al., 2012; Spiegel et al., 2013). ApoE4 is a genetic risk factor in AD that induces learning and memory deficits primarily in female mice (Raber et 

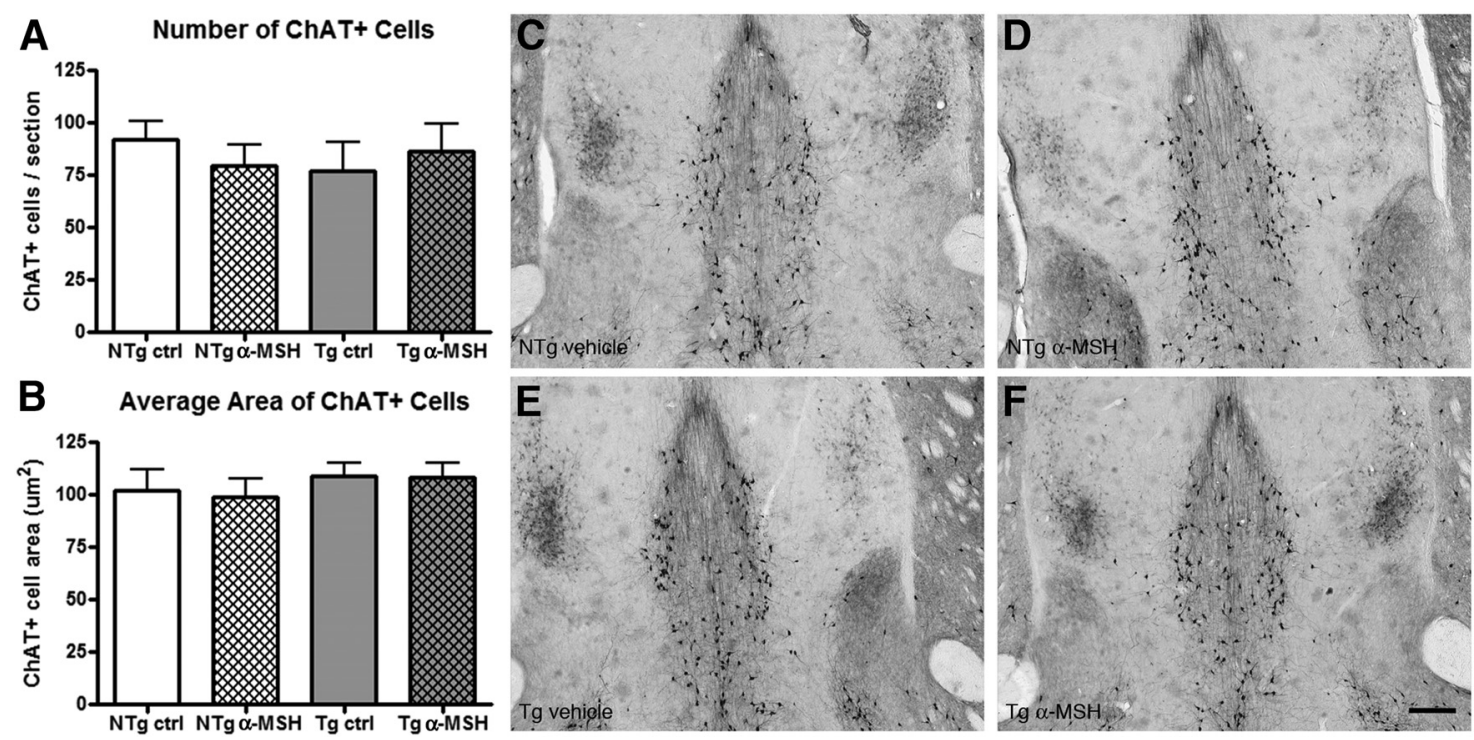

Figure 5. ChAT + cholinergic phenotype in the medial septum. $A, B, \operatorname{TgCRND} 8$ mice do not show a decrease in the number or area of ChAT + cells in the medial septum $(p=0.38$ and $p=0.58$ respectively). $\alpha$-MSH treatment does not alter the numbers or area of ChAT + cells in either TgCRND8 (number, $p=0.57$; area, $p=0.95$ ) or NTg mice (number, $p=0.46$; area, $p=0.77$ ). $\boldsymbol{C}-\boldsymbol{F}$, Representative photomicrographs of the ChAT + cholinergic cells in the medial septum in NTg vehicle-treated (C), NTg $\alpha$-MSH-treated (D), Tg vehicle-treated (E), and Tg $\alpha$-MSH-treated $(\boldsymbol{F})$ mice. Data represent mean \pm SEM, $n=6$ per group. Scale bar, $100 \mu \mathrm{m}$.
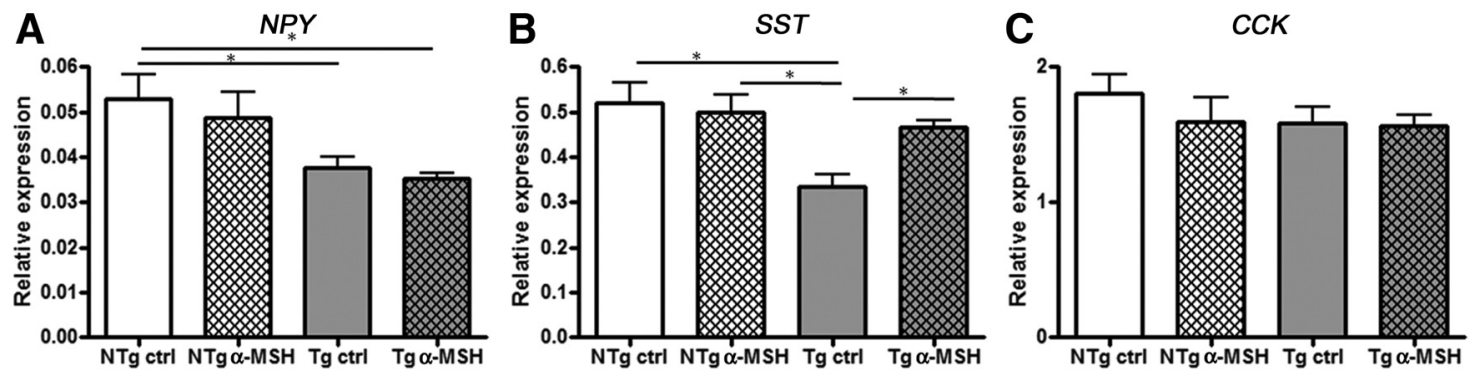

Figure 6. Effect of $\alpha$-MSH treatment on GABAergic neuronal subtypes in the hippocampus. GABAergic neurons can be divided into subtypes according to the neuropeptide expressed. $A-C$, In the hippocampus, mRNA expression of $N P Y(\boldsymbol{A})$ and SST $(\boldsymbol{B})$ is significantly decreased in TgCRND8 mice ( $p=0.01$ and $p=0.038$ respectively), but not CCK (C). $\alpha$-MSH treatment rescued SSTmRNA levels $(\boldsymbol{B})$ but does not affect NPY $(\boldsymbol{A})$ or $C \mathrm{CK}(\boldsymbol{C})$ expression. Data represent mean \pm SEM, $n=6-7$ per group, ${ }^{*} p<0.05$.

al., 1998). Aged ApoE4 knock-in female mice exhibit decreased GAD67+ and SST + cells in the hilus of the hippocampus, which is correlated with spatial memory (Andrews-Zwilling et al., 2010). The toxic effect of the ApoE4( $\Delta 272-\Delta 299)$ fragment in female mice depends on tau expression and results in loss of SST + and NPY + GAD67 + cells in the hilus (Andrews-Zwilling et al., 2010). These data are in agreement with $A P P \times \mathrm{Tau}^{-1-}$ mice, which demonstrated that cognitive loss in the $\operatorname{TgAPP}$ mouse was dependent on the expression of tau (Roberson et al., 2007). In contrast, aging male ApoE4 knock-in mice exhibit intact spatial memory with increasing expression of GABAergic interneurons in the hilus of the hippocampus (Leung et al., 2012). In aged F344 rats, animals with reduced numbers of GAD67+ SST + cells in the hilus of the hippocampus showed impairment in spatial memory, while littermates without spatial deficits had no GABAergic neuronal deficits (Spiegel et al., 2013). In outbred rats, GAD67+ and SST+ interneurons are preferentially lost in the stratum oriens with age (Stanley et al., 2012). The SST + cell loss leads to cognitive dysfunction and seizures as a result of decreased inhibitory control over entorhinal input to CA1 pyramidal cells (Stanley et al., 2012). These combined studies demonstrate the important link between GABAergic neuronal and cognitive function, more specifically the SST-expressing interneurons.
Our results demonstrate that in the septohippocampal pathway, loss of GABAergic GAD67+ and SST+ interneurons precedes loss of cholinergic ChAT + cells. Similarly, other AD mouse models show loss of hippocampal GAD67, SST, and NPY mRNA and immunoreactive cells without loss of cholinergic ChAT+ cells in the septum or cholinergic fibers in the hippocampus (Ramos et al., 2006; Loreth et al., 2012). These combined results suggest that GABAergic dysfunction precedes cholinergic dysfunction and that the GABAergic system is an earlier target for possible $\mathrm{AD}$ interventions.

In TgCRND8 mice, $\alpha$-MSH rescues spatial memory and prevents changes in anxiety. However, treatment did not alter $\mathrm{A} \beta$ levels in TgCRND8 mice. $\alpha$-MSH treatment was initiated therapeutically when $\mathrm{A} \beta$ pathology is well established in an attempt to more closely model human AD patients. Although we did not detect a difference in $\mathrm{A} \beta$ and amyloid load after $\alpha$-MSH treatment, we cannot rule out the role of specific toxic $A \beta$ oligomeric species present in small amounts. In contrast, prophylactic treatment with a potent $\alpha$-MSH analog before the onset of $\mathrm{A} \beta$ pathology for an extended period of 18 weeks reduced $A \beta$ deposits and $\mathrm{A} \beta 42$ levels in the brain of 3xTg-AD mice (Giuliani et al., 2014). There are a number of differences between these models and experimental paradigms. The TgCRND8 model is an aggressive 
A SST + cells in s.o. of CA1

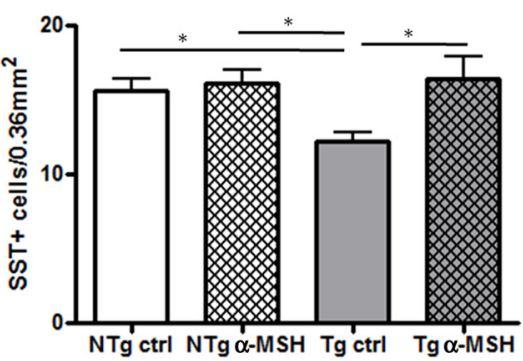

B

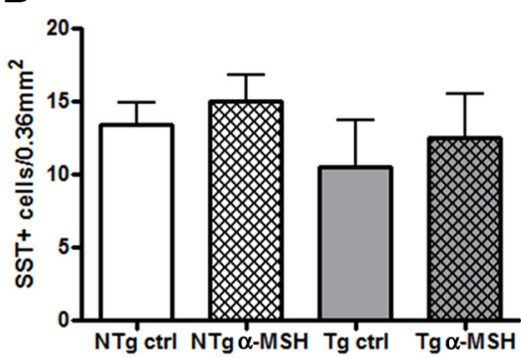

C

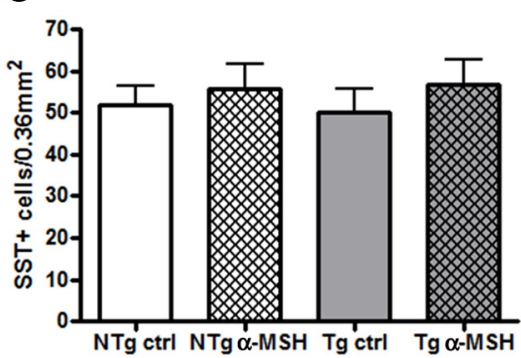

Tg vehicle

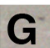

$\operatorname{Tg} \alpha-M S H$
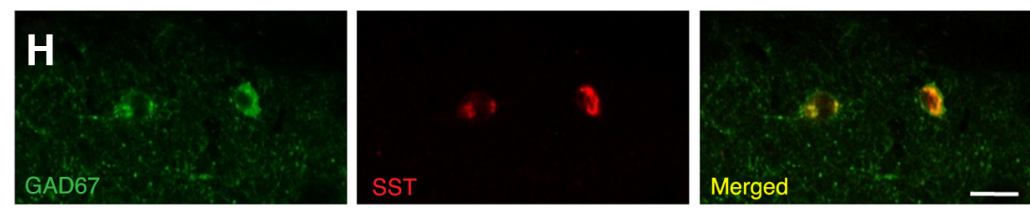

Figure 7. Effect of $\alpha$-MSH treatment on SST + cells in the hippocampus. A, SST + cells in the stratum oriens of the CA1 is significantly decreased in TgCRND8 mice and rescued by $\alpha$-MSH treatment. $B, C$, Neither genotype nor $\alpha$-MSH treatment altered the number of SST + cells in the CA3 region $(\boldsymbol{B})$ or the hilus $(\boldsymbol{C})$ of the hippocampus. $\boldsymbol{D}-\mathbf{G}$, Representative photomicrographs of the SST + cells in the CA1 region of the hippocampus in NTg vehicle-treated $(\boldsymbol{D}), \mathrm{NTg} \alpha$-MSH-treated $(\boldsymbol{E})$, Tg vehicle-treated $(\boldsymbol{F})$, and $\operatorname{Tg} \alpha$-MSH-treated (G) mice. $\boldsymbol{H}$, SST + cells colocalize with GAD67+ GABAergic interneurons in the CA1 stratum oriens of the hippocampus. Data represent mean \pm SEM, $n=6-11$ per group, ${ }^{*} p<0.05$. Scale bars: SST IHC, $100 \mu \mathrm{m} ;$ GAD67/SST colocalization, $25 \mu \mathrm{m}$.

mouse overexpressing five copies of $A P P$, while the $3 \mathrm{xTg}$ mouse model expresses a single copy of APP and thus will have substantially reduced $A \beta$ levels. The nature of the treatment paradigm, therapeutic versus prophylactic, may also have contributed to the different outcomes, as passive immunization strategies have shown prophylactic but not therapeutic benefit (Janus et al., 2000; Morgan et al., 2000; Das et al., 2001). An increasing number of studies have shown cognitive improvement after different treatments without altering A $\beta$ levels (Janus et al., 2000; Yiu et al., 2011; Callaway, 2012; Francis et al., 2012b).

In our study, independent of changes in A $\beta$ load, $\alpha-\mathrm{MSH}$ treatment improved cognition by preserving the GABAergic system. For the first time, $\alpha$-MSH has been shown to modulate the
GABAergic system and preserve SST + interneurons in the hippocampus. Although both SST and NPY are decreased in the CSF and brain of $\mathrm{AD}$ patients, human and animal studies found no correlation between NPY expression and cognition (Alom et al., 1990; Karl et al., 2008). In contrast, decreased SST levels in $\mathrm{AD}$ patients are correlated with cognitive dysfunction and intracerebroventricular administration of SST improved cognition and altered anxiety (Tamminga et al., 1987; Engin et al., 2008; Tuboly and Vécsei, 2013). In mouse models, SST intracerebroventricular administration was shown to affect anxiety by altering hippocampal theta rhythm (Engin et al., 2008), thus preservation of SST + cells in $\alpha$-MSH-treated TgCRND8 mice may have prevented anxiety changes in TgCRND8 mice. In relation to memory, administration of SST intracerebroventricularly to rats improved memory whereas depleting SST with cysteamine caused memory impairment (Vécsei et al., 1984; DeNoble et al., 1989). SST administration also rescued memory retention deficits caused by drug-induced or lesion-induced cholinergic dysfunction (Matsuoka et al., 1994). SST + interneurons in the stratum oriens induce increased inhibition onto CA1 pyramidal neurons, a function necessary in the hippocampaldependent trace eyeblink-conditioning task (McKay et al., 2013). SST+ cells in the hippocampus also form long-range projections to both the septum and the entorhinal cortex. These projections target local interneurons and modulate synchronized theta oscillations between the hippocampus and entorhinal cortex, which are critical for temporal and spatial coding of spatial memory (Buzsáki, 2002; Melzer et al., 2012). Consistent with our study, Tg2576 mice exhibit decreased anxiety and disinhibition as a function of increasing $\mathrm{A} \beta$ burden (Ognibene et al., 2005) and a loss of SST + interneurons (Perez-Cruz et al., 2011). These behavioral deficits have been proposed to correlate with the lack of inhibition that is seen in a subpopulation of AD patients (Starkstein et al., 2004; Lesser and Hughes, 2006). Together these studies help to establish the function of SST + interneurons in behavioral phenotypes and preservation of SST interneurons in TgCRND8 mice leading to cognitive improvement.

Overall, our results demonstrate that in the septohippocampal pathway, GABAergic deficits precede cholinergic deficits. $\alpha$-MSH targets the early GABAergic deficit and prevents the loss of SST + cells to improve spatial memory and prevent changes in anxiety, independent of altering $A \beta$ levels in the brain. Our results present a proof of concept that cognition can be improved by preserving the GABAergic system, in particular SST+ in- 
terneurons. In addition, $\alpha$-MSH emerges as a peptide that is neuroprotective against degeneration of the GABAergic system.

\section{References}

Alom J, Galard R, Catalan R, Castellanos JM, Schwartz S, Tolosa E (1990) Cerebrospinal fluid neuropeptide Y in Alzheimer's disease. Eur Neurol 30:207-210. CrossRef Medline

Andrews-Zwilling Y, Bien-Ly N, Xu Q, Li G, Bernardo A, Yoon SY, Zwilling D, Yan TX, Chen L, Huang Y (2010) Apolipoprotein E4 causes age- and Tau-dependent impairment of GABAergic interneurons, leading to learning and memory deficits in mice. J Neurosci 30:13707-13717. CrossRef Medline

Arai H, Moroji T, Kosaka K, Iizuka R (1986) Extrahypophyseal distribution of alpha-melanocyte stimulating hormone (alpha-MSH)-like immunoreactivity in postmortem brains from normal subjects and Alzheimertype dementia patients. Brain Res 377:305-310. CrossRef Medline

Bellucci A, Luccarini I, Scali C, Prosperi C, Giovannini MG, Pepeu G, Casamenti F (2006) Cholinergic dysfunction, neuronal damage and axonal loss in TgCRND8 mice. Neurobiol Dis 23:260-272. CrossRef Medline

Buzsáki G (2002) Theta oscillations in the hippocampus. Neuron 33:325340. CrossRef Medline

Callaway E (2012) Alzheimer's drugs take a new tack. Nature 489:13-14. CrossRef Medline

Caruso C, Carniglia L, Durand D, Gonzalez PV, Scimonelli TN, Lasaga M (2012) Melanocortin 4 receptor activation induces brain-derived neurotrophic factor expression in rat astrocytes through cAMP-protein kinase A pathway. Mol Cell Endocrinol 348:47-54. CrossRef Medline

Chishti MA, Yang DS, Janus C, Phinney AL, Horne P, Pearson J, Strome R, Zuker N, Loukides J, French J, Turner S, Lozza G, Grilli M, Kunicki S, Morissette C, Paquette J, Gervais F, Bergeron C, Fraser PE, Carlson GA et al. (2001) Early-onset amyloid deposition and cognitive deficits in transgenic mice expressing a double mutant form of amyloid precursor protein 695. J Biol Chem 276:21562-21570. CrossRef Medline

Costa A, Bini P, Hamze-Sinno M, Moglia A, Franciotta D, Sinforiani E, Ravaglia S, Bole-Feysot C, Hökfelt T, Déchelotte P, Fetissov SO (2011) Galanin and $\alpha$-MSH autoantibodies in cerebrospinal fluid of patients with Alzheimer's disease. J Neuroimmunol 240- 241:114-120. CrossRef Medline

Cui X, Weng YQ, Frappé I, Burgess A, Girão da Cruz MT, Schachner M, Aubert I (2011) The cell adhesion molecule L1 regulates the expression of choline acetyltransferase and the development of septal cholinergic neurons. Brain Behav 1:73-86. CrossRef Medline

Das P, Murphy MP, Younkin LH, Younkin SG, Golde TE (2001) Reduced effectiveness of Abeta1-42 immunization in APP transgenic mice with significant amyloid deposition. Neurobiol Aging 22:721-727. CrossRef Medline

Davies P, Terry RD (1981) Cortical somatostatin-like immunoreactivity in cases of Alzheimer's disease and senile dementia of the Alzheimer type. Neurobiol Aging 2:9-14. CrossRef Medline

Davis KL, Mohs RC, Marin D, Purohit DP, Perl DP, Lantz M, Austin G, Haroutunian V (1999) Cholinergic markers in elderly patients with early signs of Alzheimer disease. JAMA 281:1401-1406. CrossRef Medline

Deacon RM, Rawlins JN (2006) T-maze alternation in the rodent. Nat Protoc 1:7-12. CrossRef Medline

DeKosky ST, Ikonomovic MD, Styren SD, Beckett L, Wisniewski S, Bennett DA, Cochran EJ, Kordower JH, Mufson EJ (2002) Upregulation of choline acetyltransferase activity in hippocampus and frontal cortex of elderly subjects with mild cognitive impairment. Ann Neurol 51:145-155. CrossRef Medline

Del Vecchio RA, Gold LH, Novick SJ, Wong G, Hyde LA (2004) Increased seizure threshold and severity in young transgenic CRND8 mice. Neurosci Lett 367:164-167. CrossRef Medline

DeNoble VJ, Hepler DJ, Barto RA (1989) Cysteamine-induced depletion of somatostatin produces differential cognitive deficits in rats. Brain Res 482:42-48. CrossRef Medline

Dournaud P, Cervera-Pierot P, Hirsch E, Javoy-Agid F, Kordon C, Agid Y, Epelbaum J (1994) Somatostatin messenger RNA-containing neurons in Alzheimer's disease: an in situ hybridization study in hippocampus, parahippocampal cortex and frontal cortex. Neuroscience 61:755-764. CrossRef Medline

Engin E, Stellbrink J, Treit D, Dickson CT (2008) Anxiolytic and antidepressant effects of intracerebroventricularly administered somatostatin: be- havioral and neurophysiological evidence. Neuroscience 157:666-676. CrossRef Medline

Esclapez M, Tillakaratne NJ, Kaufman DL, Tobin AJ, Houser CR (1994) Comparative localization of two forms of glutamic acid decarboxylase and their mRNAs in rat brain supports the concept of functional differences between the forms. J Neurosci 14:1834-1855. Medline

Forslin Aronsson A, Spulber S, Oprica M, Winblad B, Post C, Schultzberg M (2007) Alpha-MSH rescues neurons from excitotoxic cell death. J Mol Neurosci 33:239-251. CrossRef Medline

Forslin Aronsson S, Spulber S, Popescu LM, Winblad B, Post C, Oprica M, Schultzberg M (2006) Alpha-melanocyte-stimulating hormone is neuroprotective in rat global cerebral ischemia. Neuropeptides 40:65-75. CrossRef Medline

Francis BM, Kim J, Barakat ME, Fraenkl S, Yücel YH, Peng S, Michalski B, Fahnestock M, McLaurin J, Mount HT (2012a) Object recognition memory and BDNF expression are reduced in young TgCRND8 mice. Neurobiol Aging 33:555-563. CrossRef Medline

Francis BM, Yang J, Hajderi E, Brown ME, Michalski B, McLaurin J, Fahnestock M, Mount HT (2012b) Reduced tissue levels of noradrenaline are associated with behavioral phenotypes of the TgCRND8 mouse model of Alzheimer's disease. Neuropsychopharmacology 37:1934-1944. CrossRef Medline

Freund TF, Buzsáki G (1996) Interneurons of the hippocampus. Hippocampus 6:347-470. CrossRef Medline

Gilmor ML, Erickson JD, Varoqui H, Hersh LB, Bennett DA, Cochran EJ, Mufson EJ, Levey AI (1999) Preservation of nucleus basalis neurons containing choline acetyltransferase and the vesicular acetylcholine transporter in the elderly with mild cognitive impairment and early Alzheimer's disease. J Comp Neurol 411:693-704. CrossRef Medline

Giuliani D, Ottani A, Minutoli L, Di Stefano V, Galantucci M, Bitto A, Zaffe D, Altavilla D, Botticelli AR, Squadrito F, Guarini S (2009) Functional recovery after delayed treatment of ischemic stroke with melanocortins is associated with overexpression of the activity-dependent gene Zif268. Brain Behav Immun 23:844-850. CrossRef Medline

Giuliani D, Zaffe D, Ottani A, Spaccapelo L, Galantucci M, Minutoli L, Bitto A, Irrera N, Contri M, Altavilla D, Botticelli A, Squadrito F, Guarini S (2011) Treatment of cerebral ischemia with melanocortins acting at MC 4 receptors induces marked neurogenesis and long-lasting functional recovery. Acta Neuropathol 122:443-453. CrossRef Medline

Giuliani D, Bitto A, Galantucci M, Zaffe D, Ottani A, Irrera N, Neri L, Cavallini GM, Altavilla D, Botticelli AR, Squadrito F, Guarini S (2014) Melanocortins protect against progression of Alzheimer's disease in triple-transgenic mice by targeting multiple pathophysiological pathways. Neurobiol Aging 35:537-547. CrossRef Medline

Görtz N, Lewejohann L, Tomm M, Ambrée O, Keyvani K, Paulus W, Sachser N (2008) Effects of environmental enrichment on exploration, anxiety, and memory in female TgCRND8 Alzheimer mice. Behav Brain Res 191: 43-48. CrossRef Medline

Hanna A, Horne P, Yager D, Eckman C, Eckman E, Janus C (2009) Amyloid beta and impairment in multiple memory systems in older transgenic APP TgCRND8 mice. Genes Brain Behav 8:676-684. CrossRef Medline

Harrison FE, Hosseini AH, McDonald MP (2009) Endogenous anxiety and stress responses in water maze and Barnes maze spatial memory tasks. Behav Brain Res 198:247-251. CrossRef Medline

Hawkes CA, Deng L, Fenili D, Nitz M, McLaurin J (2012) In vivo uptake of $\beta$-amyloid by non-plaque associated microglia. Curr Alzheimer Res 9:890-901. CrossRef Medline

Huang Q, Tatro JB (2002) Alpha-melanocyte stimulating hormone suppresses intracerebral tumor necrosis factor-alpha and interleukin-1beta gene expression following transient cerebral ischemia in mice. Neurosci Lett 334;186-190. CrossRef Medline

Hyde LA, Kazdoba TM, Grilli M, Lozza G, Brusa R, Brussa R, Zhang Q, Wong GT, McCool MF, Zhang L, Parker EM, Higgins GA (2005) Ageprogressing cognitive impairments and neuropathology in transgenic CRND8 mice. Behav Brain Res 160:344-355. CrossRef Medline

Janus C, Pearson J, McLaurin J, Mathews PM, Jiang Y, Schmidt SD, Chishti MA, Horne P, Heslin D, French J, Mount HT, Nixon RA, Mercken M, Bergeron C, Fraser PE, St George-Hyslop P, Westaway D (2000) A beta peptide immunization reduces behavioural impairment and plaques in a model of Alzheimer's disease. Nature 408:979-982. CrossRef Medline

Jolas T, Zhang XS, Zhang Q, Wong G, Del Vecchio R, Gold L, Priestley T (2002) Long-term potentiation is increased in the CA1 area of the hip- 
pocampus of APP(swe/ind) CRND8 mice. Neurobiol Dis 11:394-409. CrossRef Medline

Karl T, Duffy L, Herzog H (2008) Behavioural profile of a new mouse model for NPY deficiency. Eur J Neurosci 28:173-180. CrossRef Medline

Katona I, Acsády L, Freund TF (1999) Postsynaptic targets of somatostatinimmunoreactive interneurons in the rat hippocampus. Neuroscience 88: 37-55. CrossRef Medline

Kennard JA, Woodruff-Pak DS (2011) Age sensitivity of behavioral tests and brain substrates of normal aging in mice. Front Aging Neurosci 3:9. CrossRef Medline

Krantic S, Isorce N, Mechawar N, Davoli MA, Vignault E, Albuquerque M, Chabot JG, Moyse E, Chauvin JP, Aubert I, McLaurin J, Quirion R (2012) Hippocampal GABAergic neurons are susceptible to amyloid- $\beta$ toxicity in vitro and are decreased in number in the Alzheimer's disease TgCRND8 mouse model. J Alzheimers Dis 29:293-308. CrossRef Medline

Lalonde R (2002) The neurobiological basis of spontaneous alternation. Neurosci Biobehav Rev 26:91-104. CrossRef Medline

Lanctôt KL, Herrmann N, Mazzotta P, Khan LR, Ingber N (2004) GABAergic function in Alzheimer's disease: evidence for dysfunction and potential as a therapeutic target for the treatment of behavioural and psychological symptoms of dementia. Can J Psychiatry 49:439-453. Medline

Lesser JM, Hughes S (2006) Psychosis-related disturbances. Psychosis, agitation, and disinhibition in Alzheimer's disease: definitions and treatment options. Geriatrics 61:14-20. Medline

Leung L, Andrews-Zwilling Y, Yoon SY, Jain S, Ring K, Dai J, Wang MM, Tong L, Walker D, Huang Y (2012) Apolipoprotein E4 causes age- and sex-dependent impairments of hilar GABAergic interneurons and learning and memory deficits in mice. PLoS One 7:e53569. CrossRef Medline

Loreth D, Ozmen L, Revel FG, Knoflach F, Wetzel P, Frotscher M, Metzger F, Kretz O (2012) Selective degeneration of septal and hippocampal GABAergic neurons in a mouse model of amyloidosis and tauopathy. Neurobiol Dis 47:1-12. CrossRef Medline

Matsuoka N, Maeda N, Yamaguchi I, Satoh M (1994) Possible involvement of brain somatostatin in the memory formation of rats and the cognitive enhancing action of FR121196 in passive avoidance task. Brain Res 642: 11-19. CrossRef Medline

McGeer PL, McGeer EG, Suzuki J, Dolman CE, Nagai T (1984) Aging, Alzheimer's disease, and the cholinergic system of the basal forebrain. Neurology 34:741-745. CrossRef Medline

McKay BM, Oh MM, Disterhoft JF (2013) Learning increases intrinsic excitability of hippocampal interneurons. J Neurosci 33:5499-5506. CrossRef Medline

McLaurin J, Kierstead ME, Brown ME, Hawkes CA, Lambermon MH, Phinney AL, Darabie AA, Cousins JE, French JE, Lan MF, Chen F, Wong SS, Mount HT, Fraser PE, Westaway D, St George-Hyslop P (2006) Cyclohexanehexol inhibitors of Abeta aggregation prevent and reverse Alzheimer phenotype in a mouse model. Nat Med 12:801-808. CrossRef Medline

Melzer S, Michael M, Caputi A, Eliava M, Fuchs EC, Whittington MA, Monyer H (2012) Long-range-projecting GABAergic neurons modulate inhibition in hippocampus and entorhinal cortex. Science 335:15061510. CrossRef Medline

Morgan D, Diamond DM, Gottschall PE, Ugen KE, Dickey C, Hardy J, Duff K, Jantzen P, DiCarlo G, Wilcock D, Connor K, Hatcher J, Hope C, Gordon M, Arendash GW (2000) A beta peptide vaccination prevents memory loss in an animal model of Alzheimer's disease. Nature 408:982_985. CrossRef Medline

Ognibene E, Middei S, Daniele S, Adriani W, Ghirardi O, Caprioli A, Laviola G (2005) Aspects of spatial memory and behavioral disinhibition in Tg2576 transgenic mice as a model of Alzheimer's disease. Behav Brain Res 156:225-232. CrossRef Medline

Palop JJ, Chin J, Roberson ED, Wang J, Thwin MT, Bien-Ly N, Yoo J, Ho KO, Yu GQ, Kreitzer A, Finkbeiner S, Noebels JL, Mucke L (2007) Aberrant excitatory neuronal activity and compensatory remodeling of inhibitory hippocampal circuits in mouse models of Alzheimer's disease. Neuron 55:697-711. CrossRef Medline

Perez-Cruz C, Nolte MW, van Gaalen MM, Rustay NR, Termont A, Tanghe A, Kirchhoff F, Ebert U (2011) Reduced spine density in specific regions of CA1 pyramidal neurons in two transgenic mouse models of Alzheimer's disease. J Neurosci 31:3926-3934. CrossRef Medline

Perry EK, Tomlinson BE, Blessed G, Bergmann K, Gibson PH, Perry RH (1978) Correlation of cholinergic abnormalities with senile plaques and mental test scores in senile dementia. Br Med J 2:1457-1459. CrossRef Medline

Prut L, Belzung C (2003) The open field as a paradigm to measure the effects of drugs on anxiety-like behaviors: a review. Eur J Pharmacol 463:3-33. CrossRef Medline

Raber J, Wong D, Buttini M, Orth M, Bellosta S, Pitas RE, Mahley RW, Mucke L (1998) Isoform-specific effects of human apolipoprotein $\mathrm{E}$ on brain function revealed in ApoE knockout mice: increased susceptibility of females. Proc Natl Acad Sci U S A 95:10914-10919. CrossRef Medline

Rainero I, May C, Kaye JA, Friedland RP, Rapoport SI (1988) CSF alphaMSH in dementia of the Alzheimer type. Neurology 38:1281-1284. CrossRef Medline

Ramos B, Baglietto-Vargas D, del Rio JC, Moreno-Gonzalez I, Santa-Maria C, Jimenez S, Caballero C, Lopez-Tellez JF, Khan ZU, Ruano D, Gutierrez A, Vitorica J (2006) Early neuropathology of somatostatin/NPY GABAergic cells in the hippocampus of a PS1 $\times$ APP transgenic model of Alzheimer's disease. Neurobiol Aging 27:1658-1672. CrossRef Medline

Roberson ED, Scearce-Levie K, Palop JJ, Yan F, Cheng IH, Wu T, Gerstein H, Yu GQ, Mucke L (2007) Reducing endogenous tau ameliorates amyloid beta-induced deficits in an Alzheimer's disease mouse model. Science 316:750-754. CrossRef Medline

Rubio SE, Vega-Flores G, Martínez A, Bosch C, Pérez-Mediavilla A, del Río J, Gruart A, Delgado-García JM, Soriano E, Pascual M (2012) Accelerated aging of the GABAergic septohippocampal pathway and decreased hippocampal rhythms in a mouse model of Alzheimer's disease. FASEB J 26:4458-4467. CrossRef Medline

Sarkar S, Légrádi G, Lechan RM (2002) Intracerebroventricular administration of alpha-melanocyte stimulating hormone increases phosphorylation of CREB in TRH- and CRH-producing neurons of the hypothalamic paraventricular nucleus. Brain Res 945:50-59. CrossRef Medline

Sharma S, Rakoczy S, Brown-Borg H (2010) Assessment of spatial memory in mice. Life Sci 87:521-536. CrossRef Medline

Spiegel AM, Koh MT, Vogt NM, Rapp PR, Gallagher M (2013) Hilar interneuron vulnerability distinguishes aged rats with memory impairment. J Comp Neurol 521;3508-3523. CrossRef Medline

Stanley EM, Fadel JR, Mott DD (2012) Interneuron loss reduces dendritic inhibition and GABA release in hippocampus of aged rats. Neurobiol Aging 33:431.e1-e13. CrossRef Medline

Starkstein SE, Garau ML, Cao A (2004) Prevalence and clinical correlates of disinhibition in dementia. Cogn Behav Neurol 17:139-147. CrossRef Medline

Stewart S, Cacucci F, Lever C (2011) Which memory task for my mouse? A systematic review of spatial memory performance in the Tg2576 Alzheimer's mouse model. J Alzheimers Dis 26:105-126. CrossRef Medline

Tamminga CA, Foster NL, Fedio P, Bird ED, Chase TN (1987) Alzheimer's disease: low cerebral somatostatin levels correlate with impaired cognitive function and cortical metabolism. Neurology 37:161-165. CrossRef Medline

Tuboly G, Vécsei L (2013) Somatostatin and cognitive function in neurodegenerative disorders. Mini Rev Med Chem 13:34-46. CrossRef Medline

Vécsei L, Király C, Bollók I, Nagy A, Varga J, Penke B, Telegdy G (1984) Comparative studies with somatostatin and cysteamine in different behavioral tests on rats. Pharmacol Biochem Behav 21:833-837. CrossRef Medline

Verret L, Mann EO, Hang GB, Barth AM, Cobos I, Ho K, Devidze N, Masliah E, Kreitzer AC, Mody I, Mucke L, Palop JJ (2012) Inhibitory interneuron deficit links altered network activity and cognitive dysfunction in Alzheimer model. Cell 149:708-721. CrossRef Medline

Wilson JF (1988) Low permeability of the blood-brain barrier to nanomolar concentrations of immunoreactive alpha-melanotropin. Psychopharmacology 96:262-266. Medline

Yiu AP, Rashid AJ, Josselyn SA (2011) Increasing CREB function in the CA1 region of dorsal hippocampus rescues the spatial memory deficits in a mouse model of Alzheimer's disease. Neuropsychopharmacology 36: 2169-2186. CrossRef Medline 